\title{
The workers with Disabilities' Access to Workplace Inclusion in Postmodern Model Perspective
}

\author{
Argyo Demartoto \\ Faculty of Social and Political Sciences Universitas Sebelas Maret \\ argyodemartotofisip@staff.uns.ac.id
}

\begin{abstract}
ABSTRAK
People with disabilities are often labeled negatively and treated discriminatively within a community, including in the workplace, so that only a few of them are absorbed in either formal or informal job. Meanwhile, they are entitled to get a productive and reasonable job in order to realize their aspiration, to improve their life condition, and to participate actively within the community. This article studies the workers with disabilities' access to workplace inclusion in Postmodern Model Perspective in Surakarta. Accidental sampling was used to select informant; data collection was carried out through observation, in-depth interview, and document. Data validation was carried out using method and data source triangulation. The result of research showed that the access of the workers with disabilities to workplace inclusion has not been optimal yet, because the opportunity was still more limited compared with that for their non-disabled counterparts. Although inclusive work environment has diverse potential human resources and the workers with disabilities' perspective, creativity, innovation, and problem-solving ability have not been utilized maximally. In the construction process, workers with disabilities should actively participate in planning, implementation, and monitoring and evaluation so that the guarantee of workers with disabilities' accessibility to a building, transportation and communication media, workplace inclusion, and many facilities can be met. The improvement of accessibility in the term of independency, rehabilitation, and social grant, and the maintenance of social wellbeing level and equal right to grow and to develop people with disabilities' talent, ability, and social life are important to develop workplace inclusion. Prioritizing and respecting pluralism, equity, dignity, and active public participation simultaneously and sustainably will lead to the realization of an inclusive society.
\end{abstract}

KEYWORDS Accessibility | Workers with Disabilities | Diversity | Inclusion | Workplaces

\section{INTRODUCTIONS}

People with disabilities are part of the community with equal position, right, obligation, and role in many aspects of life and livelihood including reasonable education, occupation, and livelihood. It has been confirmed in Declaration on the Rights of Disabled Persons (1975) and Republic of Indonesia's Law Number 4 of 1997 about People with Disabilities. A variety of international standards about disability and its status have been formulated, for example, International Labor Organization's (ILO) Convention Number 111 of 1958 about Discrimination in Job and Position ratified on June 7, 1999; ILO's Convention
Number 159 of 1983 about Vocational and Occupation Rehabilitation (People with Disabilities) not ratified yet; and United Nations' Convention of 2006 about People with Disabilities' Rights and Preference Protocol ratified on November 30, 2011.

ILO has promoted and ascertained the disabilities perspective in all aspects of manpower policy and regulation, legislation implementation and enforcement, and effective policy for people with disabilities, and has developed skill and job opportunity to people with disabilities based on the principles of equal opportunity, treatment, and mainstreaming 
into vocational rehabilitation. Those aspects contribute to poverty reduction and socially and economically inclusion of people with disabilities throughout the world, including Indonesia (Filmer 2008; $\mathrm{Mi}^{-}$ tra et al, 2011; Mont and Cuong 2011; Strauser ed 2014; Mizunoya et al 2016).

The protection of workers with disabilities' rights in Indonesia have been governed in several regulations: Republic of Indonesia's Law Number 4 of 1997 about People with Disabilities, Republic of Indonesia's Government Regulation Number 43 of 1998 about the Attempt of Improving Social Wellbeing of People with Disabilities, Republic of Indonesia's Law Number 39 of 1999 about Human Rights, Minister of Labor and Transmigration's Regulation No. KEP-205/MEN/1999, Republic of Indonesia's Law Number 28 of 2002 about Building Construction, Republic of Indonesia's Law Number 25 of 2009 about Public Service and Republic of Indonesia's Law Number 8 of 2016. Nevertheless, the people of disabilities' accessibility is still very limited and even there has been no clear legal or administrative sanction imposed by the Republic of Indonesia's Ministry of Labor to public or private institutions unwilling to employed people with disabilities.

Considering the data of National Labor Force Survey (Indonesian: SAKERNAS) in 2017, the people with disabilities at productive age consist of 21,930,529 people and out of this number, $11,224,673$ people or $51.18 \%$ belong to the labor force. It includes $10,810,451$ people or $96.31 \%$ of labor force with disabilities working (employed) and 414,222 people or $3.69 \%$ not working (unemployed). The Informal sector is the most preferred one to people with disabilities. Meanwhile, there are $10,705,856$ people or $48.82 \%$ belonging labor force without disabilities in detail consisting of 206,163 people or 1.93\% studying at school, 5,911,017 people or $55.21 \%$ dealing with domestic chores, and the rest of 4,588,676 people or $42.86 \%$. The number of people with disabilities by type and sub-district in Surakarta in 2016 can be seen in table 1.

\section{Table 1.}

The proportion of People with Disabilities by Type and Sub-District in Surakarta in 2016

\begin{tabular}{|l|c|c|c|c|}
\hline Sub district & $\begin{array}{c}\text { Physical } \\
\text { disability }\end{array}$ & Blind & $\begin{array}{c}\text { Mental } \\
\text { Retarded }\end{array}$ & Deaf/Mute \\
\hline Laweyan & 43 & 1 & 6 & 1 \\
\hline Serengan & 18 & - & 2 & 3 \\
\hline $\begin{array}{l}\text { Pasar } \\
\text { Kliwon }\end{array}$ & 14 & 2 & 15 & 1 \\
\hline Jebres & 34 & 2 & 24 & 7 \\
\hline Banjarsari & 14 & 3 & 12 & 11 \\
\hline Total & $\mathbf{1 2 3}$ & $\mathbf{8}$ & $\mathbf{5 9}$ & $\mathbf{2 3}$ \\
\hline 2015 & 714 & 159 & 391 & 207 \\
\hline 2014 & 321 & 152 & 163 & 150 \\
\hline 2013 & 120 & 30 & 135 & 63 \\
\hline 2012 & 587 & 314 & 782 & 305 \\
\hline \multicolumn{2}{|c|}{ (Source: Social Service of Surakarta 2017) } \\
\end{tabular}

So far, people tend to assess physical disability negatively regardless of intellectual ability and skill the people with disabilities have (Macy 1996). The main problem in the work realm is negative label inherent, so that there are insult and skepticism to the job applicants with disabilities (Eiesland 1994; Davis 1996). There is a misconception among government, non-government, or private institutions on workers with disabilities, in which they always doubt their ability because they take into account more productivity and profit obtained by the institution and limited fund related to the recruitment of workers with disabilities (Fuller 2010; Hernandez et al 2011; Strauser ed 2014). People with disabilities themselves are very sensitive to body image, self-acceptance, surrounding environment, freedom, and performance achievement, thereby are getting irritated and angry easily to others and even to themselves (Macy 1996; Davis 1996; Barnes and Mercer 2010). It makes their accessibility to job opportunity low, but currently, some public, non-public, or private institutions begin to give people with disabilities the job opportunity. In addition to, they begin to provide facilities and physical infrastructure accessible to people with disabilities as indicated with building and infrastructure, instrument and facilitation service to people with disabilities including toilet, oblique parking lot, and handrail as the access path to enter into the building. This article studies the workers with disabilities' access to workplace inclusion in Postmodern Model Perspective in Surakarta. 


\section{LITERATURE REVIEW}

In the work environment, layers of diversity are distinguished based on personality; internal dimension such as age, sex, sexual orientation, race and ethnic; external dimension such as different geographic location, income and life habit; and organizational dimension, such as seniority, different position and job division (Gardenswartz and Rowe 2003). It can be seen in figure 1 .

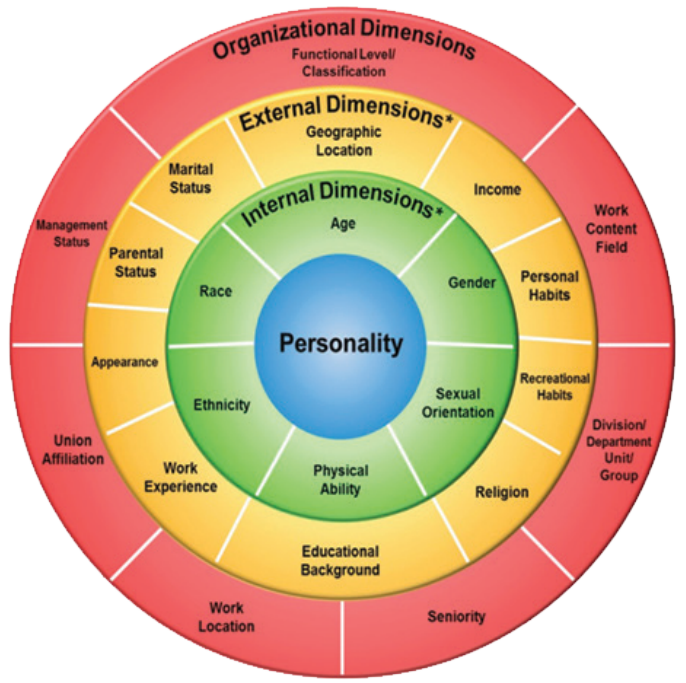

(Source: Gardenswartz and Rowe 2003)

Figure 1.

The Four Layers of Diversity Model

A variety of policies related to people with disabilities are inseparable from a community's perspective on disabilities (Davis 1996). Departing from Moral Model stating that disabilities are punishment or sin due to human's deed breaking social and religious norms prevailing, so that community isolates, alienates, kills, and disposes of people with disabilities (Eiesland 1994; Coleridge 1997). Medical model or Individual Model views disabilities as physical and mental weaknesses, thereby having disabilities or limitation in doing activities. Disability is considered a personal tragedy that should be healed; therefore Medical Rehabilitation Center is established for people with disabilities (WHO 2008). Through the appeal to respecting human's rights including the people with disabilities', Civil Model arises because every individual has equal rights. Disability is a community problem needing advocacy concerning legal and social system. Law experts, disabled activists, and demand for the removal of discrimination, prejudice, alienation, and denial against their basic rights. This activity aims to improve people with disabilities' access to economic, social, education, health service facilities, occupational right, and environmental resource (Barnes and Mercer 2010).

Postmodern Model or Social Model criticizes the existence of people with disabilities holistically and comprehensively related to all aspects of society life. Social model views people with disabilities using Social Oppression Theory, takes social action to make the people with disabilities independent and responsible, to make the community undiscriminating, respecting the people with disabilities' right so that social change occurs. It aims to realize the inclusive society including workplace inclusion in which all elements of society have equal opportunity to contribute to community life. For that reason, pluralism, equity, dignity, and active participation of community members in undertaking social activities run simultaneously and in a balanced manner to realize the inclusive society (Oliver 1999; Miller and Katz 2002; National Service Inclusion Project 2004).

Workplace inclusion is a part of human right principles such as justice, respect, equality, dignity, and autonomy promoted and being the part of an organization's daily objective and behavior. Workplace inclusion should enforce equality policy and human right, work condition, dignity in the workplace, worker wellbeing, and fair recruitment and procurement practices, and involve the workers in developing policy. There are diverse workers coming from either local community or users. All workers are entitled to have progressed, to identify constraint, and to make a decision in dealing with it. Work institution should identify potential tension in the workplace and act to anticipate and to deal with it. The inclusive strategy is completely supported and promoted by senior staff (Equality and Human Rights Commission Guidance 2010). Employee retention, institution or company image, market expansion, and absenteeism and turnover rate decrease, and such forms of workplace accommodation as vocational counseling and guidance, education and advocacy right, work schedule change, work organization, and special transportation are 
the manifestation of Workplace Inclusion (Macy 1996; Roberge et al 2011; Nevala et al 2015).

\section{METHOD}

This research was taken place in Surakarta Indonesia because there were workers with disabilities working in both public and private institutions in this area. Analysis units of this qualitative research with phenomenological approach were workers with disabilities, Chairperson of Yayasan Talenta Surakarta (Indonesian: Surakarta Talenta Foundation), personnel staff of Surakarta Labor Service, and disable activist. Accidental sampling was used to select informants. Techniques of collecting data used were observation, in-depth interview and documentation relevant to Haul activity. Data validation was carried out using data source triangulation. Phenomenology analysis was conducted interactively with Postmodern Model Perspective including data reduction, data display, and conclusion drawing (Creswell 2013; Miles et al 2014).

\section{RESULTS AND DISGUSSION}

It is difficult to mention the certain number of workers with disabilities in Surakarta, and even Surakarta Labor Service does not have valid data because neither public nor private institution employing disabled people reports it. The diversity of workers, particularly those with a disability, is important to apply. An appropriate socialization in government institution or company and employees with disabilities as the part of human diversity that has equal human rights to other humans with different sex, skin color, ethnic group, religion, race, and class is very important to do in order to appreciate the people with disabilities' potency and ability and to grow sense of disability in work environment (Derrida 1978; Irigaray 2005). The inclusive work environment can enrich creativity, innovation, and problem-solving ability because of the more diverse potency of human resource and perspective owned (Equality and Human Rights Commission Guidance 2010; Roberge et al 2011; Buchanan and Huczynski 2017). Diversity without inclusion does not work (Miller and Katz 2002).
A disabled academician and accountant of Universitas Sebelas Maret graduated from a foreign university stated that:

\begin{abstract}
"In inclusion, an individual feels a sense of belonging, respected, appreciated for his/her uniqueness, supported and getting others'/neighborhood's commitment, thereby can maximize his/her capacity. It means that every individual is involved in an organization and put it to be the mission of the organization, thereby becoming a work culture and realized in work organization, motivation, and high spirit".
\end{abstract}

Work culture building on persistence values, sincerity, and high commitment can encourage the implementation of inclusive work system including both espoused values and enacted values (Miller and Katz, 2002; National Service Inclusion Project 2004; Dwiyanto, 2012; Groysberg and Connolly 2013; Buchanan and Huczynski 2017).

Adisabled worker in Surakarta City Government stated that:

"Symbol or attribute is also important to improve the credibility of company elements such as working uniform or other accessories giving an inclusive impression. Attitude and behavior to diversity can create result in the dissenting opinion and the working institution needs them".

Workplace inclusion, according to a quadriplegic worker in a company in Surakarta, will make the workers feeling appreciated and respected because they are treated prestigiously, appreciated for their talent and skill, happy, more motivated and aware of the advantage of inclusion. A personal staff in Surakarta Labor Service stated that:

"A workplace should be designed in such a way that facilitates the workers with disability through a coordinated attempt by taking into account personal need, work environment, institution, and legal responsibility. It is intended for the development of workers with disabilities".

The development of cohesive, collaborative, and creative work environment as a means of encouraging the growth of sustainable business starting with a clear and right understanding on diversity and inclusion (Roberge et al 2011; International Labour Organization 2013). Addendum of USAID/ Indonesia's Development Innovation Acceleration published on June 24, 2014, a document number 
Indonesia-BAA-DIA, is intended to get Expression of interest in research, innovation, and cooperation to support USAID/Indonesia's Inclusive Workforce Development (IWD) program. The objective is to promote more inclusive economic growth and to deal with an increasingly wide income gap by improving the development of workers for poor and vulnerable people including those with disabilities. It can be accomplished by reaching potential partners that have been recognized for their skill in various relevant fields by co-creating, co-designing, co-investing and cooperating with partners. Through IWD, USAID attempts to improve the leveraging power of many elements in a comprehensive worker development system to encourage collective impact and transformative change, improving the poor and vulnerable people's access to high-quality and relevant worker development, the training opportunity from private sector, and the government's decision making capacity at province and regency/city levels in developing job training and opportunity (Hudson Jr. 2014; USAID 2015).

Diversity maturity and institution or company inclusion can be identified and improved. At the basic layer, diversity issue and inclusion are implemented concretely in the workplace. Awareness means that leader and organizer have limited awareness of the advantage of worker diversity and inclusive culture. Understanding and application through development action mean that all workers understand that diversity serves to create an inclusive work environment. Integrated means that leader and employee have knowledge and skill concerning how to improve company's performance through managing worker diversity effectively toward workplace inclusion and sustainability, in which diversity maturity and highest inclusion are achieved when all employees show off inclusive behavior consistently and consciously or when company has felt the benefit of workplace inclusion (CLC Human Resources, 2012; Hernandez et al, 2012; Hudson Jr, 2014). Sapto Nugroho as the Director of Yayasan Talenta Surakarta argued that:

"For all components of the institution or company ranging from leader to the bottom-level employees to have an equal understanding on workers with a disability, an attempt is required to equate the perception. Company and all employees should be able to determine the coverage of diversity specifically and clearly".

Diversity management becomes a means of improving performance, employee and customer service and satisfaction. Diversity approach can be used to improve the individual, team, or organizational performances through many existing practices and procedures (Thomas and Ely 1996; Nilson 1997; Phillips and O'Reilly 1998). In Indonesia, according to a personnel staff of Surakarta Labor Service,

"There is a stipulation stating that employers and officers with an authority of conducting worker recruitment, selection, and placement processes should have an understanding about the principles of worker recruitment, selection, and placement in open, free, objective, fair, and equal manners while considering right, opportunity equality, transparency, and ability. In this case, the company can cooperate with the government, utilizing social media, and special education institution. Prospect workers with disabilities are entitled to acquire opened and objective information about a job opportunity. It impacts the achievement of workplace inclusion and the company's larger opportunity of getting qualified workers with disabilities".

The selection process should emphasize on justice or equality aspect, while different treatment occurs only in the term of representing marginal or minority group in the company. The meeting between the institution or company and the parents' of prospect workers with a disability is conducted to comply with the openness/transparency aspect ( $\mathrm{Po}_{-}$ erwanti 2017). A disabled worker in Surakarta City Government suggested that:

\footnotetext{
"Job training is a rehabilitating activity focusing on developing physical, mental, and social abilities of people with disabilities in order to be able to undertake their social function reasonably according to their talent, ability, education, and experience. The company can conduct worker development activity by giving people with disabilities the equal opportunity of developing their career".
}

Diversity and inclusion training is required to improve the awareness of individual difference and change in the workforce and to create the behavioral change necessary to manage and to work effectively in diverse workers. Training is the key 
to minimizing disruptions likely related to the significant improvement of individual and organizational performances in workplace diversity (Wentling et.al 1997; Strauser ed 2014; Saebones et al 2015; Mizunoya et al; 2016). Fair rewarding is useful to create workplace inclusion because workers with disabilities feel being respected and appreciated for the uniqueness they have and their contribution to the company (Miller and Katz 2002). In workplace inclusion, the use of attributes and symbols psychologically can improve the credibility of all company elements (Dwiyanto 2012). Counseling activity can support the creation of an inclusive work environment, meaning that the company provides service paying attention to the psychological condition of workers with disability and attempting to give a solution to their work problem. The designation of facilitator for workers with disabilities as the agent of change can help the company to transmit the idea, view, and practice of workplace inclusion to other workers (Nilson 1997; International Labour Organization 2015). Meanwhile, the attempt of minimizing conflict between workers can be taken by repositioning the position to the field with lower conflict risk, understanding and knowing the condition of workers with disabilities with all of their limitations (Thomas and Ely 1996; Roberge et al 2011).

According to Sapto Nugroho, the Director of Surakarta Talenta Foundation:

"There are still some architectural constraints in various public areas in Surakarta: sidewalk not disabilities-friendly, uneven road surface, high road edge, too narrow door, too slippery floor, no appropriate parking lot, no lift, too narrow sanitation facility, stairs without safeguarding fence, window or advertisement board inhibiting the road, and so on. It becomes problems for people with disabilities with a certain type and degree of disabilities so that they cannot realize their right equality as the members of the community."

A lecturer of Regional and City Planning in Engineering Faculty of Universitas Sebelas Maret stated that:

"The architectural constraints affect workers with disabilities who use the wheelchair, semi-ambulance, and have a manipulatory disability (muscle movement difficulty), sensory disability such as blind and deaf, and intellectual disability (mental retarded). A worker with disabilities in Surakarta's government said that the constraint encountered by wheelchair users as the result of architectural design in the building where he works includes the sudden change of surface height levels such as in stairs or ditch, no slope link between road and sidewalk, no adequate space for knee under the table or wash basin, no adequate space to bend, too narrow door and corridor, uneven road surface due to stones thereby inhibiting the running of wheelchair, too heavy door thereby is difficult to open and too high location of buttons."

It is line with the opinion of the author's colleague in The Faculty of Economics and Business in Universitas Sebelas Maret. Meanwhile, a quadriplegic worker in a company in Solo having difficulty to walk but not requiring wheelchair complains about too high stairs constructed in their company, too slippery floor, too narrow turnstile or automatically closing door moving too rapidly, lift door closing too rapidly, and escalator without the handle and moving too rapidly. Meanwhile, the difficulties the blind workers encounter are particularly: no signboard or signs that can be heard or seen with limited visual ability indicating floor number in multistoried building, small obstacles such as the window open outward of advertisement board put on sidewalk, dazzling or too dull light, and lift without actual (touchable) hints to distinguish many types of button or voice hints to show the number of floors. Many deaf workers have lip reading difficulty in the auditorium with poor lighting, and cannot hear danger sign sound. Meanwhile, mentally retarded workers look for the way into new environment difficultly because there is no clear and standardized signboard. Therefore, information should be presented in the format accessible to people with disabilities, for example, Braille, loudspeaker, capitalized a letter, signal use, sign language, and etc. Surakarta often called as the paradise for people with a disability even implements workplace inclusion less optimally in various workplaces. So, what about in other areas of Indonesia? It, of course, should get our big attention. In the construction process, people with disabilities should actively participate in planning, implementation, and monitoring and evaluation so that the guarantee of people with disabilities' accessibility to the building, 
transportation and communication media, workplace inclusion and many facilities can be met.

As a cross-sector issue, disabilities need synergic cooperation to deal with (Demartoto 2005). People with disabilities are entitled to be supported with (others') attempts of facilitating them to be independent/not dependent on others (Coleridge 1997). In this case, government, institution, and disabilities observer's role is highly needed to support the unemployment alleviation program. Empowerment measure through improving people with disabilities' ability can make them more powerful, meaning capable of doing something beneficial in community development. People with disabilities become important considering that they have potency and willingness to change into the better one, according to potency, natural resource, and local wisdom existing surrounding (Barnes and Mercer 2010). In addition, they are also entitled to get medical, psychological and functional services, medical and social rehabilitation, education, skill training, consultation, job placement, and all types of services enabling them to develop their capacity and skill optimally, thereby accelerating social reintegration and integration processes. This attempt should be conducted as marginalizing people with disabilities from labor force will lead the state loses 3\%-7\% of GDP.

However, workers with disabilities should readily compete tightly in entering into job realm and be equipped with intellectual ability and high-quality skill according to the job need (Jones 2016). Workplace inclusion should be supported with $\mathrm{co}^{-}$ operation between public or private institutions and related institutions; coworkers; work counseling and the role of facilitator for workers with a disability. Communication constraint, low productivity, and institutions or companies' less readiness to place and no professionals handling the workers by disabilities should be anticipated and overcome.

\section{CONGLUSION}

The accessibility of disabled workers to workplace inclusion in Surakarta has not been optimal yet, because the opportunity is still more limited compared with that for their non-disabled counter- parts. The improvement of accessibility in the term of independence, rehabilitation, and social grant, and the maintenance of social wellbeing level and equal right to grow and to develop people with disabilities' talent, ability, and social life are important to develop workplace inclusion. Prioritizing and respecting pluralism, equity, dignity, and active public participation simultaneously and sustainably will lead to the realization of an inclusive society.

\section{REFERENCES}

Badan Pusat Statistik (BPS). 2017. Survei Angkatan Kerja Nasional (SAKERNAS) 2017. Jakarta: Badan Pusat Statistik (BPS).

Barnes, Colin and Mercer, Geof. 2010. Exploring Disability 2nd ed. Cambridge. UK: Polity Press.

Buchanan, David A and Huczynski, Andrzej A. 2017. Organizational Behavior 9th ed. UK: Pearson.

CLC Human Resources. 2012. "Creating Competitive Advantage Through Workplace Diversity." The Corporate Executive Board Company. Accessed September 15, 2018. (https:// manualzz.com/doc/12509726/creating-competitive-advantage-through-workforce-diversit...)

Coleridge, Peter. 1997. Pembebasan dan Pembangunan. Yogyakarta: Pustaka Pelajar.

Creswell J W 2013 Qualitative Inquiry and Research Design: Choosing Among Five Approaches 3rd ed (London: Sage Publication)

Davis, Leonard J. 1996. The Disability Studies Readers. London: Routledge.

Demartoto, Argyo. 2007. Menyibak Sensitivitas Gender dalam Keluarga Difabel. Surakarta: UNS Press.

Derrida, Jacques. 1978. Writing and Difference Translated by Alan Bass. Chicago: University of Chicago Press.

Dwiyanto, Agus. 2012. Manajemen Pelayanan Publik: Peduli Inklusif dan Kolaborasi. Yogyakarta: UGM Press. 
Eiesland, Nancy. L. 1994. The Disabled God: Towards a Liberatory Theology of Disability. Nashville: Abingdon Press.

Equality and Human Rights Commission Guidance. 2010. An employer's guide to Greating an Workplace Inclusion. England: Equality and Human Rights Commission Publish.

Filmer, Deon. 2008. Disability, poverty, and schooling in developing countries: Results from 14 household surveys. The World Bank Economic Review, 22 (1): 141-163.

Fuller, Sandra K. 2010. Employment for the developmentally disabled via one-stop centers. Medical Humanities Dissertations: Disabilities Studies Capella University

Gardenswartz, Lee and Rowe, Anita. 2003, Diverse Teams at Work: Capitalizing on the Power of Diversity. 2nd ed. Alexadria, Virginia, USA: Society for Human Resource Management (SHRM).

Groysberg, Boris and Connolly, Katherine. 2013. "Great Leaders Who Make the Mix Work". Harvard Business Review 91 (9): 68-76.

Hernandez, Brigida; Chen, Bin; Araten-Bergman, Tal; Levy, Joel; Kramer, Michael and Rimmerman, Arie. 2012. "Workers with Disabilities: Exploring the Hiring Intentions of Non-profit and For-profit Employers." Employee Responsibilities and Rights Journal 24 (4): 237-249.

Hudson, Swinton W Jr. 2014. "Diversity in the Workforce." Journal of Education and Human Development. 3 (4): 73-82.

Irigaray, Luce. 2005. An Ethics of Sexual Difference Translated by Carolyn Burke and Gillian C. Gill. London: Continuum.

International Labour Organization. 2013. Pedoman ILO tentang Pengelolaan Penyandang Disabilitas di Tempat Kerja. Jakarta: ILO

International Labour Organization. 2013. "Inclusion of people with disabilities in Indonesia." Accessed September 15, 2018. (https://www. ilo.org/jakarta/whatwedo/publications/ WCMS_233427/lang--en/index.htm)
International Labour Organization. 2015. ILO and disability inclusion (GED/PARDEV).Geneva, Switzerland: International Labour Office.

Jones, Melanie K. 2016. "Disability and labor market outcomes." IZA World of Labor, 253: $1-10$.

Macy, Granger. 1996. "Accommodating employee with disabilities: a matter of attitude". Journal of Managerial Issues 8 (1):78-91.

Miles M B, Huberman A M and Saldaña J. 2014 Qualitative Data Analysis: A Methods Sourcebook and The Coding Manual for Qualitative Researchers. Thousand Oaks, CA: Sage Publications).

Miller, Frederick A. and Katz, Judith H. 2002. The Inclusion Breakthrough: Unleashing the Real Power of Diversity. San Francisco: Berrett-Koehler Publishers, Inc.

Mitra, Sophie; Posarac, Aleksandra and Vick, Brandon. 2011. Disability and poverty in developing countries: A snapshot from the World Health Survey (SP Discussion Paper No. 1109). Washington,DC: The World Bank.

Mizunoya, Suguru; Mitra, Sophie and Yamasaki, Izumi. 2016. Towards inclusive education: The impact of disability on school attendance in developing countries (Innocenti Working Paper No. 2016-03). Florence, Italy: UNICEF Office of Research.

Mont, Daniel and Cuong, Nguyen V. 2011. "Disability and poverty in Vietnam." The World Bank Economic Review, 25 (2): 323-359.

National Service Inclusion Project. 2004. Inclusion, Creating an Inclusive Environment. A Handbook for the Inclusion of People with Disabilities in National and Community Service Programs. Massachusetts, Boston: Corporation for National and Community Service. 
Nevala, Nina; Pehkonen, Irmeli; Koskela, Inka; Ruusuvuori, Johanna and Anttila, Heidi. 2015. "Workplace Accommodation Among Persons with Disabilities: A Systematic Review of Its Effectiveness and Barriers or Facilitators." Journal of Occupational Rehabilitation. 25, (2): $432-448$.

Nilson, Julie. 1997. "Developing Diversity Program.” Healthcare Executive. 12 (4) :16.

Oliver, Michael J., 1999. Capitalism, Disability and Ideology: A Materialist Critique of the Normalization Principle. London: University of Greenwich.

Phillips, Katherine W and O'Reilly, Charles A. 1998. "Demography and Diversity in Organizations." Research in Organizational Behavior, 20: 77-140.

Poerwanti, Sari D. 2017. "Pengelolaan Tenaga Kerja Difabel untuk Mewujudkan Workplace Inclution." INKLUSI: Journal of Disability Studies, 4 (1): $1-24$

Roberge, Marie-Élène; Lewicki, Roy; Hietapelto, Amy and Abdyldaeva, Aijana. 2011. "From Theory To Practice: Recommending Supportive Diversity Practices." Journal of Diversity Management - Second Quarter 6 (2):1-20.

Strauser, David R. ed. 2014. Career Development, Employment, and Disability in Rehabilitation From Theory to Practice. NewYork: Springer Publishing Company, LLC.
Srbønes, Ann-Marit; Bieler, Rosangela B; Baboo, Nafisa; Banham, Louise; Singal, Nidhi; Howgego, Catherine and Riis-Hansen, Trine C. 2015. Towards a disability inclusive education (Background paper for the Oslo Summit on Education for Development). Oslo: The World Bank.

Thomas, David A and Ely, Robin. 1996. "Making differences matter: A new paradigm for managing diversity." Harvard Business Review 74 (5): 79-90.

USAID. 2015. "Workforce Development Accelerator." Accessed September 15, 2018. (https:// www.usaid.gov/indonesia/partnership-opportunities/challenge-inclusive-workforce-development)

Wentling, Rose M and Palma-Rivas, Nilda. 1997. Diversity in the Workforce Series Report \#1: Diversity in the Workforce: A Literature Review MDS- 934. Berkeley, GA: National Center for Research in Vocational Education Graduate School of Education University of California at Berkeley.

World Health Organization. 2008. International Classification of Functioning, Disability and Health Nonserial Publication Series. Geneva, Switzerland: World Health Organization. 